\title{
A Professional Competences' Diagnosis in Education for Sustainability: A Case Study from the Standpoint of the Education Guidance Service (EGS) in the Spanish Context
}

\author{
Fátima Poza-Vilches * ${ }^{\mathbb{D}}$, Abigail López-Alcarria and Nerea Mazuecos-Ciarra \\ Department Methods of Research, Faculty of Education, University of Granada, 10871 Granada, Spain; \\ abigail@ugr.es (A.L.-A.); mazue@correo.ugr.es (N.M.-C.) \\ * Correspondence: fatimapoza@ugr.es
}

Received: 14 February 2019; Accepted: 11 March 2019; Published: 14 March 2019

\begin{abstract}
Currently, all members of the educational community have a relevant role in the development of professional competences on the sustainability of students. This is supported by the findings obtained by different research studies carried out in different countries and which show the need to characterize and evaluate the practice of EGS as key agents in the training and counseling of teachers on sustainability topics, which, in turn, is the goal of this study. To address this, we have conducted an exploratory study based on the case study of EGS members in the metropolitan area of Granada (Spain) that has helped us to profile the professional practice of its members in the development of professional competences in Education for Sustainable Development (ESD). Answers to a questionnaire provided by 43 teachers who are linked to the EGS have been investigated in addition to an interview to six formal members of the EGS. Results evidence that transmit some values over others correlates positively with the type of competences for sustainability that they promote. Therefore, this shows the interrelation of these competencies with the teaching-learning process and, consequently, with the promotion of an education for sustainability. We conclude that counseling on participatory methodologies, working on values, competences, and curricular sustainability, as well as the cross-curricular nature of the content that is imparted, are the most effective ways from which these teacher guidance services can promote the development of professional competences linked to sustainability in schools.
\end{abstract}

Keywords: educational guidance service; sustainability professional competences; education for sustainability development; professional development; case study

\section{Introduction}

We live on a finite planet. We are depleting non-renewable resources and consuming renewable resources faster than they can regenerate. Globally, we are witnessing a dizzying loss of biodiversity, climate change, pollution, deforestation, and various other environmental problems. These problems are accompanied by strong social inequalities, which are marked by economic, political, and environmental issues that must be addressed within the field of education.

Educators face a great challenge, and the Education for Sustainability Development (ESD) is presented as a necessary tool to address it, especially given that it is the key to generating more awareness and sustainable societies. Likewise, in order to educate about sustainability, certain key competencies are necessary to enable students to constructively and responsibly participate in society [1-8]. The concept of competency can be understood as 'a functionally linked complex of knowledge, skills, and attitudes that enable successful task performance and problem solving; when 
applied to sustainability complexes of knowledge, skills, and attitudes that enable successful task performance and problem solving with respect to real-world sustainability problems, challenges, and opportunities' ([2], p. 242, [3], p. 204).

It is in this vein that this exploratory and descriptive study based on a case study has been undertaken, the objective of which is to analyze educational practices for sustainability linked to the Educational Guidance Service (EGS) as well as the key competencies that both the team of counsellors and teachers that make up the EGS highlight as references for the development of their professional practice. The analyzed EGS is a public service provided by the Government and aims to advise and guide primary and secondary school teachers to improve their teaching practice. In this case, we have focused on the guiding members of EGS and primary education teachers who are beneficiaries of the work of this service, which is later specified in the section "description of the case study."

Based on approaches of current literature and different guidelines that promote international initiatives related to the education for sustainability ('Sustainable Development Goal on education, the Education 2030 Agenda and Framework for Action, the Global Action Programme (GAP) on Education for Sustainable Development (ESD), and the Sustainable Lifestyles and Education program of the 10-Year Framework of Programs on Sustainable Consumption and Production -10YFP-). We intend to analyze the trend of this guidance service ([9], p. 1173 [10]). We, therefore, consider it interesting to analyze how the studied EGS advocates for professional practices focused on a more qualitative and transformative approach, which is one of the key principles of education for sustainability.

\section{Theoretical Background}

\subsection{Education for Sustainable Development (ESD)}

ESD is a key concept for education in the new millennium because it provides a distinctive focus on addressing a number of important aspects of education as a whole including access to it, the relevance of acquired skills or equity, and inclusion. A literature review indicates that, currently, the integration of sustainability in education requires changes in thinking and practice that can be perceived in some cases by the educational community as great challenges due to the lack of training and tools to face them [11,12]. 'Sustainability education implies a transformation in educational thinking and practice through which education becomes more transformative learning. This indicates a paradigm that is holistic, systemic, and participative' ([11], p. $110[13,14])$. Therefore, ESD is much more than just teaching principles and knowledge of sustainability. It consists of educating so that there is a profound social transformation opening avenues toward more sustainable societies $[2,9-12,15,16]$. In this sense, four axes have been proposed from which to orient the ESD that highlights integrality and cross-curricular approaches [16]: 'Improve access and retention rates in quality basic education,' 'Reorient existing educational programs to achieve sustainability,' 'Increase public understanding and awareness in relation to sustainability,' and 'Provide training to all sectors of the workforce.' The first two axes refer mainly to the processes of change in the field of formal education, and the third and fourth focus especially on non-formal and informal education. Therefore, for the development of these axes, coordinated activities are required between the formal, non-formal, and informal educational sectors $[17,18]$.

On the other hand, ESD goes beyond knowledge related to the environment, society, and the economy. ESD also contemplates learning skills, perspectives, and values that encourage the search for more sustainable ways of life. It also involves the study of local and global problems and their relationship with each other. It points out the need for these five components (knowledge, skills, perspectives, values, and problems) to be included in the formal academic programs aimed at addressing Sustainable Development and use experience-based learning as a tool to introduce sustainability into the classroom $[8,19]$. Within this task, there are different relevant factors that increase the quality of educational process and that include students, teachers, guidance services, social agents, 
and the learning approach, didactic material, learning climate, evaluation processes, training teachers or continuous professional development, and revision of the curriculum. These factors, ultimately, favor the improvement of educational process from an effective teaching approaches and strategies, adequate training of teachers, and safe and effective learning environments $[9,10,20,21]$.

The implementation of ESD is such a challenge that it is necessary to refocus curricula and educational models toward considering students as operating beings and, at the same time, part of both a local and global community and who, therefore, must learn to feel and live in harmony with all other beings on the planet as well as with the environment, by taking into account the interrelationships and dynamics that occur $[9,17,18,22]$.

\subsection{Competences for Sustainable Development}

This shared effort to educate for sustainability has the objective for promoting the development of competencies that empower people to reflect on their own actions, by taking into consideration their social, economic, environmental, and cultural effects, both current and future, and from a local and global perspective, with the ultimate goal of promoting sustainable societies [16]. In this sense, we want to corroborate if the teacher group and guidance team investigated in our case study, tend to correlate SD with environmental aspects, and less often with social or economic aspects or, on the contrary, they manifest an integral conception of SD linked to the three pillars that sustain it (social, economic, and environmental) since it has been corroborated by other researchers in this field [23-31].

In order to educate on sustainability, as previously mentioned, certain key competences are necessary to enable students to constructively and responsibly participate in society [2-4]. These competencies include cognitive, motivational, affective, and procedural elements. In order to acquire the key competences required for ESD.

- An innovative methodology, which combines the acquisition of knowledge with its adequate application to educational practice, is needed.

- We must pay attention to the teaching-learning processes centered on the ethical criteria of social justice, equity, solidarity, and respect for the environment,

- Models that focus on practice and on project-based methods need to be incorporated.

Therefore, they have a multidimensional nature because educating for sustainability implies knowing, understanding, acting, and being [32]. These key competencies linked to sustainability can be summarized in seven points (Figure 1) that make visible the integral perspective of what educating for sustainability means $[2,3,5,33]$. 


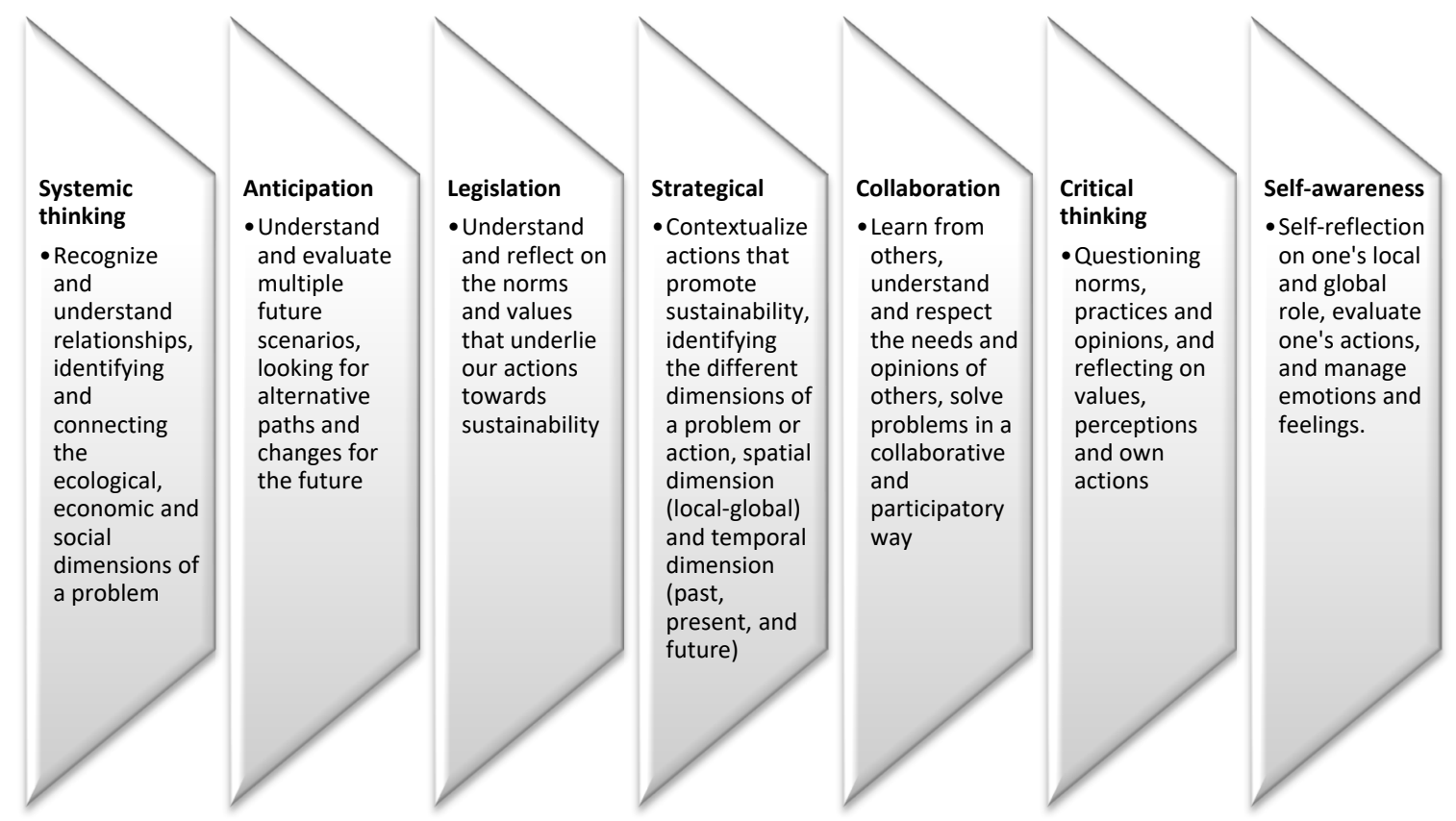

Figure 1. Competencies on sustainability. Adaptation of References [2,3,5,34].

From a competency perspective, ESD is a great challenge and, at the same time, a great opportunity, since it is in line with education's ultimate goal: to prepare students for their future and to assume their responsibility in it [34-36].

To achieve the ESD objectives, it is essential to rethink educational methodologies, since it is necessary for students to acquire competencies and sustainable values through teaching-learning processes that place them as active subjects for their education and that encourage participatory and democratic processes [17,18]. 'This imperative is further emphasized by UNESCO's Education Strategy (2014-2021), which outlines three strategic objectives: (1) to develop education systems and support educators to foster quality and inclusive lifelong learning for all, by improving learning processes and outcomes, (2) to empower learners to be creative and responsible global citizens by, for instance, strengthening education for sustainable development, and (3) to shape the future education agenda by rethinking education for the future' ([35], p. 406, [37]).

ESD cannot be based solely on the inclusion of content about sustainability in the curriculum, but that global changes are required in the very conception of the educational process, introducing significant changes in didactics $[34,35,38]$. 'The environmental (biophysical) dimension of sustainability has been traditionally overemphasized in SD curriculum integration. More holistic approaches stressed the importance of cultural-based approximations aimed at encouraging the understanding of the underlying causes of the unsustainability of current trends. As an example, an analysis of the political and cultural dimensions related to sustainability can facilitate a deep understanding of Earth overexploitation' ([39], p. 287). Therefore, it is time to transform learning processes by stimulating processes of critical reflection in teachers and students who question their assumptions and beliefs $[39,40]$.

\subsection{Educational Guidance Service and ESD}

Educational Guidance is revealed as a key strategy and as a transforming and innovative vehicle that contributes to the integration of ESD in education systems. In Spain, the counsellors 'are responsible for both educational guidance and for the promotion and support of the development of different educational programs. They can act as critical colleagues, advisors, and key agents for the improvement of teaching and learning processes' ([41], p. 151). On the other hand, this service also favors the vocational development of students in order to promote their academic development and 
their future inclusion in the working market. In this country, these counselors organize themselves in Educational Guidance Services. They have the ability to promote the acquisition of the knowledge, skills, attitudes, and resources that teachers will need to address the reconceptualization of the educational process that is being defended in this work $[35,39,40]$.

In Spain, the Provincial Technical Services of Spanish Educational and Professional Guidance have proposed and developed a series of innovative methodologies that are in line with ESD principles including cooperative learning, interactive groups, case studies, project-based learning, or service learning in the classroom [42]. The EGS propose that these methodologies are carried out within the classroom, and it is with this that the guidance teams have a lot to contribute, advising and motivating teachers on their implementation.

But the EGS not only works with teachers, but also has a framework of activities that covers the entire educational community. This great responsibility is also at a great advantage since analyzing it from the paradigm of sustainability, it coincides with the idea of acting overall in not just a local way, but also in a global way and valuing the interrelationships that exist between all the components [36]. For this reason, this research is framed in the context of the EGS since this organization has a broader and more systemic vision of the context in which they have developed their work and because, from this perspective, we must question ourselves (1) how do they approach teaching for sustainability? and (2) what should 'learning for sustainability' constitute within the Technical and Vocational Subjects that EGS members teach? [36,43]. In order to work on the roadmap of counselors and teachers, new ways to incorporate education for sustainability in their practice must be investigated [36,43].

\section{Description of the Case Study}

In Spain, the EGS are an external support service to a school, organized by geographical areas and educational stages and whose basic functions are related to the diagnosis, advice, and guidance of the educational community (center, students, and families). 'The work of these professionals is distinguished by the interdisciplinary and specialized nature of their interventions, by the functions of support and complement to the educational activities at the centers, and by their contribution to educational dynamization and innovation' ([44], p. 2). In this way, the EGS are seen as agents of change who have the significant function of promoting the transformation and improvement of the educational process on an individual level, but also on social and institutional levels. Key functions that are linked to the development of professional skills in ESD from all perspectives (from the management of the center, teacher training, the teaching-learning process of students, and the transfer of knowledge outside the classroom).

From these premises, this study aims to characterize the professional practice of an Educational Guidance Service in the Metropolitan Area of Granada (Spain) linked to the development of professional competencies in Education for Sustainability, in order to identify and analyze any weaknesses and recommended improvements with regard to advice and teacher training, but also from the teaching practice of teachers, as recipients of these actions.

The EGS object of this research is composed of five counsellors, with the support of two other counsellors who share their place of work with other teams, and a social educator. They regularly attend 15 educational centers for early childhood and primary education (12 Early Childhood and Primary Education Centers, two Early Childhood Education Centers, and 1 Rural Public School), and occasionally attend six secondary education centers (four high schools and two private teaching centers).

The environmental context of this EGS is geographically extensive and the associated educational centers have different characteristics. At some centers, there is a remarkable percentage of compensatory education students (ethnic minorities and immigrants) and students with specific educational support needs compared to other centers in which there are competitive students from an academic point of view. 
This area also stands out for having innovative centers - centers where innovative methodologies have been implemented and they are participating in innovative plans, projects, and programs. Some of the sustainability plans and projects that a number of centers in the area are working on include: growing in health, participation in Eco-schools (including the following programs: grow with your tree, Andalusia Botanical Gardens Network, Nature and You), the creation of a recycling corner, creation of a school garden, Red Andaluza Escuela Espacio de Paz (Peace Space School Andalusia Network), Coexistence Plan (Living Together), Plan for Equality between men and women, and Ponte en Marcha (Get Moving Project).

Given the characteristics of the area, where there are innovative centers that are fully standing behind plans and projects related to sustainability, it was considered pertinent to investigate the perception on ESD at educational centers, and undertake an analysis of competencies that participants develop around this issue.

Lastly, we consider the following, in general, to be the objectives of this study: (i) Analyze the professional practice (beliefs, attitudes, content inclusion, difficulties) of the EGS members and teaching staff linked to the development of professional competencies in Education for Sustainability, (ii) identify strengths and improvement actions linked to the Education for Sustainability from the perspective of the guidance team and teachers or those who have benefited from the work of this EGS. Both objectives are operationalized through more specific ones, such as: (1) analyze the beliefs and attitudes of members of the EGS and teaching team on ESD, (2) diagnose the deficiencies linked to the inclusion of content related to ESD, (3) identify the sustainability competencies that both counsellors and teachers promote in their professional practice, (4) characterize the difficulties that counsellors and teachers perceive when incorporating and developing key competences linked to the ESD, (5) identify strengths and proposals for improvement, both of the guidance team and the teaching practice, which channel the development of professional skills in the exercise of actions in favor of sustainability.

\section{Materials and Methods}

The complexity of the object of this study is such that approaching it through only a single approach would be insufficient, so a mixed methodology has been chosen (quantitative and qualitative) by collecting and analyzing both qualitative and quantitative data and proceeding to its subsequent integration and combined discussion, in order to obtain results that will help us to understand the studied phenomenon with more depth and breadth. 'The basic premise of this methodology is that such integration permits a more complete and synergistic utilization of data than separate quantitative and qualitative data collection and analysis' ([45], p. 1) and allows us 'to determine different versions of reality, the factors that are related to those versions in terms of power and privilege, and the making visible of the potential for social change associated' ([46], p. 7 ; [47]), which are both basic principles in the field of education for sustainability.

More specifically, our research can be identified as an exploratory and descriptive case study. This type of study tries to create descriptions by focusing the attention on the 'what is' of the educational phenomenon, going beyond the mere collection of data. It is an exploratory study that aims to investigate the problem in the context of reference. It is, therefore, an exploratory study that aims to investigate the problem in the context of reference without offering definitive solutions. The research topic is explored with different levels of deepening $[48,49]$ with the purpose of generating processes of self-reflection for the improvement of the professional practice of the participants in the study [50-52]. For this reason, the case study is confirmed as the methodological approach from which to orient this research because the questions and research aims will be addressed from the detailed analysis of the information offered by different sources of information related to the case studied. Our research has been addressed by obtaining quantitative data but also qualitative information that narrates the most relevant issues related to the case studied through illustrative key descriptions [53-56].

With regard to the strategies used to collect information, two instruments have been designed: 
(1) Questionnaire: To analyze the perception of teachers in the area and recipients of EGS actions, a Likert scale questionnaire has been designed. The questionnaire includes the following blocks: 1. Independent variables for personal identification (sex, age, years of teaching experience, academic training, educational center at which he/she currently works and subjects taught). 2. Specific questions about the research object (dependent variables). This consists of 32 items referring to five study dimensions that correspond to the research objectives: (i) beliefs and attitudes about education for sustainable development, (ii) shortcomings related to the inclusion of content related to the ESD, (iii) teaching competencies regarding sustainability, (iv) difficulties, (v) strengths and improvement proposals to include ESD in professional practice. The first four categories have been divided into eight items and the respondents address the latter through two final open-ended questions that have sought to generate reflection and self-evaluation processes. For the design of the instrument, we drew from a questionnaire that has been previously validated by experts and used to measure these dimensions as well as theoretical references related to the subject $[5,16,33]$. All the items have been written as positive statements to facilitate their understanding. Of the 32 items, four have been written reflecting negative attitudes. These have been called unfavorable items. There are five types of answers on the scale: (1) totally disagree, (2) disagree, (3) not sure, (4) agree, and (5) totally agree. The questionnaire ends with two questions that urge the inclusion of the rationale behind the answer. This way, obtaining richer and more in-depth results related to pointing out two or three needs in terms of advice, guidance, and training about ESD that are relevant to their practice. Interviewees must specify some activity, content, methodology, or specific competence linked to ESD that they consider appropriate to work on in their classroom for the improvement of the educational process.

(2) Interview: To obtain information from EGS members, a semi-structured interview was designed, based on a pre-established script with open-ended questions referring to the same study dimensions that are referred to in the questionnaire. The interview begins with personal identification questions: name, sex, age, education, years of experience, years in the EGS, and relevant educational center. The body of the interview consists of 18 questions. First, the object of the interview is discussed and the concepts of Sustainable Development and Education for Sustainability are defined. The questions revolve around the five dimensions of study that the questionnaire addresses, varying in the approach, because it aims to delve into the guidance-based perspective: (i) beliefs and attitudes about education for sustainable development, (ii) shortcomings linked to inclusion of content related to ESD, (iii) teaching guidance-based competences on sustainability issues, (iv) difficulties of ESD in formal education from a guidance-based perspective, and (v) strengths of improvement proposals from a guidance-based perspective.

The population under investigation are the members of one of the EGS from the province of Granada and the Primary Education teachers of the centers assisted by this service. In this case study, we have employed an accidental non-probabilistic sampling. All members that form part of the studied EGS as well as all teachers of all primary education centers that are subjected to its guidance have been included in the sample.

The sample consists of six counsellors and 43 primary school teachers.

The sample for the interview is composed of three female and three male counsellors, with ages ranging from 31 to 53 years old, as detailed in Table 1. 
Table 1. Features that characterize the sample of EGS members.

\begin{tabular}{cccccl}
\hline $\begin{array}{c}\text { STUDY } \\
\text { SUBJECTS }\end{array}$ & GENDER & AGE & $\begin{array}{c}\text { EXPERIENCE } \\
\text { TIME }\end{array}$ & $\begin{array}{c}\text { EXPERIENCE TIME } \\
\text { IN THIS EGS }\end{array}$ & PERSONAL BACKGROUND \\
\hline 1 & Male & 38 & 10 years & 7 years & Psychology Ph.D. \\
\hline 2 & Female & 31 & 8 months & 4 months & $\begin{array}{l}\text { Graduate in Psychology \& Master's } \\
\text { degree in high school teacher }\end{array}$ \\
\hline 3 & Female & 42 & 8 years & 5 months & $\begin{array}{l}\text { Graduate in Pedagogy, Master's } \\
\text { degree in educational psychology \& } \\
\text { Master's degree in sociocultural } \\
\text { animation and socio-educational } \\
\text { intervention }\end{array}$ \\
\hline 5 & Female & 47 & 18 years & 5 years & $\begin{array}{l}\text { Teaching diploma \& Graduate in } \\
\text { Psychology }\end{array}$ \\
\hline 5 & Male & 53 & 25 years & 3 years & \begin{tabular}{l} 
Graduate in Psychology \\
\hline
\end{tabular} \\
\hline & Female & 44 & 19 years & 2 years & $\begin{array}{l}\text { Teaching diploma, Graduate in } \\
\text { Psychopedagogy, History of Art } \\
\text { (studying) }\end{array}$ \\
\hline
\end{tabular}

As for the sample of teachers, this group is made up of 43 primary education teachers, aged between 34 and 57 years old, belonging to eight Early Childhood and Primary Education Centers in the area serviced by the EGS.

The distribution by sex is quite homogeneous with $58 \%$ female and $42 \%$ male. The average age of the teaching staff is 43.6 years old, and the average number of their years of experience as teachers is 17.2 years.

The majority of teachers have completed a Teaching Degree in Primary Education (93\%) even though there is a small sample $(7 \%)$ of teachers with other studies (English Teaching Degree or French Teaching Degree + Religion).

For the questionnaire, descriptive analyses were carried out through the SPSS v.22 software package. We have verified those items that obtained the highest and lowest averages, also taking into account their standard deviation, and analyzed which axes they belong to. As indicated above, of the 32 items, four were written reflecting negative attitudes. These are called unfavourable. Therefore, when analyzing the results, the values obtained were inverted. Those items with inverted results are: (i) 'I think that Education for Sustainability should only be encouraged in informal and non-formal educational settings,' (ii) 'only those topics that are related to natural sciences should be addressed in relation to ESD,' (iii) 'incorporation, both in the curriculum and in the teaching of aspects related to sustainable development, must be the choice of teachers,' (iv) 'my subjects do not fit with ESD.'

To analyze the answers to the two open-ended questions that conclude the questionnaire, a content analysis has been carried out.

In relation to the quality criteria of quantitative data, the reliability of the questionnaire was calculated using Cronbach's Alpha to assess reliability. This reliability has been calculated with two of the four sub-scales that make up the questionnaire and which are the central axis of this article, that is, sub-scales 'values' and 'competences,' which return a grouped value of 0.912 , reflecting the high value of the reliability.

On the other hand, since it is an instrument adapted from other authors, the applied instrument has already been validated at the construct and content level by previous research processes [5,34]. However, on our side, we have carried out the factorial analysis of both 'values' and 'competences' sub-scales, which obtained a principal factor with a saturation of all the studied variables between 0.500 and 0.858 . This shows that these two sub-scales measure the same theoretical construct (construct validity).

With regard to qualitative information, an analysis of the content of the interviews was carried out using NVivo v.10, which highlights the most relevant aspects that are of interest for this research by taking into account the five dimensions defined in the study. 
To treat this information, we have based our analysis on the four quality criteria that need to be considered in the analysis of qualitative information (credibility, applicability, consistency, and neutrality) [57]. (i) Credibility: During the analysis process, conversations were held with participants in the study to corroborate the interpretations made based on their answers. (ii) Applicability or transferability: the study has been carried out in only one EGS of the province of Granada but instruments and results obtained can be applied in other contexts with similar characteristics. (iii) Consistency: we consider that similar results would be obtained if the study was to be replicated in other EGS because the analysis has been carried out in a meticulous way from a process of triangulation of sources and techniques. (iv) Neutrality: the detailed description of the research process carried out indicated in this article shows that it has been a neutral and non-biased process.

The processing of the information obtained through the interview focuses on unveiling and comparing the attitudes, values, perceptions, difficulties, strengths, strategies, and suggestions that EGS members have about ESD. Key fragments of the respondents' answers have been collected in respect to each of these dimensions, and a final synthesis is shown with the most repeated words in the respondents' discourse through a word cluster and the repetition percentages of each one of these.

Within this fulfillment of criteria in the research, the process of triangulation is a key element. It becomes one of the basic requirements for credibility of the obtained findings, as a contrast technique that allows complementing and highlighting the convergence of information provided by different sources and by different techniques, in order to overcome methodological limitations and the subjectivity to which the qualitative methods are usually exposed [58-61].

The triangulation processes that we have carried out aim to offer confidence tests and guarantees that the results and findings proposed within this work meet the minimum requirements of credibility and rigor that have allowed us to build rich and diverse information as a result of its combination, complementation, and triangulation.

In this study, we have carried out a double triangulation since the data are crossed from the perceptions and opinions of the participating population and from the different information collection strategies carried out as it is depicted in Figure 2.

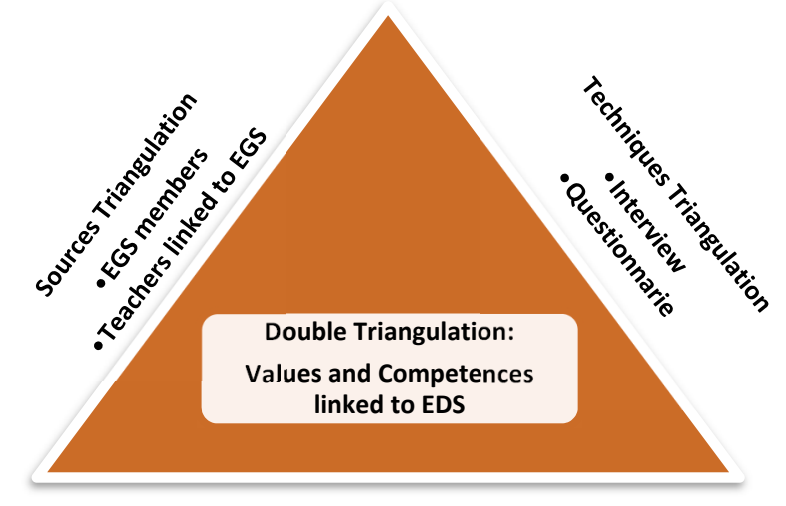

Figure 2. Type of triangulation developed within this study (own elaboration).

\section{Results and Analysis}

Based on the instruments applied, the results and analyses obtained were the following:

\subsection{Results Derived from the Questionnaire Addressed to Teachers}

When analyzing the results obtained in the questionnaire applied to 43 primary school teachers that form our sample with a $100 \%$ response rate, the following data have been extracted, which are shown grouped by research dimensions, and, within each one, the results have been ordered, according to the overall score. 


\subsubsection{Dimension 1. Teachers' Beliefs and Attitudes to ESD}

Considering the items of this dimension, the average scores given by the teaching staff are presented below (Table 2).

Table 2. Teachers' beliefs and attitudes about ESD.

\begin{tabular}{lll}
\hline \multicolumn{1}{c}{ Item } & Mean & Standard Deviation \\
\hline $\begin{array}{l}\text { All Primary education students should learn about sustainable } \\
\text { development (SD). }\end{array}$ & 4.63 & 0.49 \\
\hline $\begin{array}{l}\text { The Administration should train teachers to work from the ESD } \\
\text { approach. }\end{array}$ & 4.35 & 0.57 \\
\hline All subjects should be focused from an ESD perspective. & 3.39 & 1.18 \\
\hline I have adapted my subjects to ESD. & 3.12 & 1.07 \\
\hline $\begin{array}{l}\text { I think ESD should be encouraged only in informal and non-formal } \\
\text { educational settings. }\end{array}$ & 3.02 & 1.28 \\
\hline $\begin{array}{l}\text { Only those subjects that are related to natural sciences should be } \\
\text { addressed from the ESD perspective. }\end{array}$ & 2.88 & 1.14 \\
\hline $\begin{array}{l}\text { The incorporation into both the curriculum and teaching of aspects } \\
\text { related to SD should be left to the choice of teachers. }\end{array}$ & 2.59 & 1.29 \\
\hline My subjects do not fit into ESD teaching. & 2.47 & 1.12 \\
\hline
\end{tabular}

In this dimension, the items with the highest scores, which also show lower standard deviations, were: 'All primary education students should learn about ESD' (average: 4.63, TD: 0.49), and 'The Administration should train teachers to work from the ESD approach' (average: 4.35, TD: 0.57). These results show a positive attitude toward ESD.

However, when analyzing the items with the lowest scores, we can infer that the positive attitude towards ESD is global, since the most specific items have obtained lower scores and greater standard deviations (between 1.12 and 1.28), which show heterogeneity in the answers.

A contradiction can be observed, as the item with the highest scores states that all students in primary education should learn about ESD, but the item with the lowest score was that my subjects do not fit with EDS teaching, which highlights that they do not conceive ESD to be a cross-cutting axis that can be worked on from within all subjects. We also observe this contradiction when inferring that part of the teachers really think that ESD should not be promoted from within formal education, but from informal and non-formal educational settings.

\subsubsection{Dimension 2. Shortcomings in Regard to the Inclusion of ESD-Related Content}

The teachers surveyed the subjects to the extent to which they promote and work with content and values linked to topics related to ESD (Table 3).

Table 3. Gaps linked to the inclusion of content related to ESD.

\begin{tabular}{ccc}
\hline Item & Mean & Standard Deviation \\
\hline Coexistence norms & 4.81 & 0.39 \\
Peace & 4.77 & 0.43 \\
Conflict resolution & 4.77 & 0.43 \\
Gender equality & 4.74 & 0.44 \\
Nondiscrimination & 4.74 & 0.44 \\
Respect for the environment & 4.70 & 0.46 \\
Human rights & 4.65 & 0.48 \\
Healthy habits & 4.60 & 0.49 \\
\hline
\end{tabular}

Results show that teachers believe that they greatly promote the content and values promoted by the ESD in their classes.

Items with the highest score are: coexistence norms (4.81), peace (4.77), and conflict resolution (4.77), which are values that are deeply promoted in formal education and which have been promoted in the wider society. 
To address this dimension, there has also been an open-ended question, related to needs in terms of advice, guidance, and training in ESD. The answers obtained show that the main need identified relates to training. Many of the responses given were that they need training in relation to ESD to include content in their classroom, without specifying what type of training. Two of the teachers have specified training in methodologies related to ESD and two others with regard to the evaluation of ESD activities.

In reference to training on specific content, there is a variety of responses, and the following topics were mentioned several times: organic farming, renewable energy, and responsible consumption. These responses show that they relate the ESD exclusively to technological-environmental content, since none of the teachers mentioned other types of specific content, such as social, economic, or justice and equity issues.

Four of the responses have been related to the allocation of resources, two have mentioned material and economic resources, and two other answers note specific materials such as Integrated Didactic Units, tasks, texts, digital content, programming, and games.

\subsubsection{Dimension 3. Teaching Competencies Regarding Sustainability}

Through these questions, teachers have reflected on the sustainability competencies that they work on in their classrooms (Table 4).

Table 4. Sustainability competencies worked in the classroom.

\begin{tabular}{|c|c|c|}
\hline Item & Mean & Standard Deviation \\
\hline $\begin{array}{l}\text { Collaboration: learn from others, understand and respect the needs and opinions } \\
\text { of others, solve problems in a collaborative and participatory way. }\end{array}$ & 4.44 & 0.73 \\
\hline $\begin{array}{l}\text { Self-awareness: reflect on the role you have locally and globally, evaluate your } \\
\text { own actions, and manage emotions and feelings. }\end{array}$ & 4.14 & 0.83 \\
\hline $\begin{array}{l}\text { Problem solving: apply different problem-solving frameworks to complex } \\
\text { sustainability problems and devise solutions that promote sustainable } \\
\text { development. }\end{array}$ & 4.02 & 0.83 \\
\hline $\begin{array}{l}\text { Strategic: contextualize actions that promote sustainability by identifying the } \\
\text { different dimensions of a problem or action, spatial dimension (local-global), and } \\
\text { temporal dimension (past, present, and future). }\end{array}$ & 3.95 & 0.69 \\
\hline $\begin{array}{l}\text { Regulations: understand and reflect on the norms and values that underlie our } \\
\text { actions toward sustainability. }\end{array}$ & 3.81 & 0.73 \\
\hline
\end{tabular}

The item with the highest score is the one related to collaboration (with an average value of 4.44). This result is linked to the previous axis, which highlighted the values of coexistence norms, peace and conflict resolution, which are values that promote collaboration among students. The next item with the highest results is the one related to critical thinking (4.37), which included a reflection on one's own values, perceptions, and actions. This shows, once again, that education about values is promoted in depth within the education system.

The items with the lowest scores (although still high) are those related to the promotion of 'normative' competences (3.81) and 'systemic thinking' (3.93). These competencies are directly related to the concept of ESD since they include recognizing and understanding the interrelations of the ecological, economic, and social dimensions, and understanding the norms and values that underpin our actions towards sustainability. They are more complex competences, involving a greater cross-curricular scope. These results show that there is still work to be done in this regard. 
5.1.4. Dimension 4. Difficulties to Include ESD in the Teaching of the Subjects

According to teachers' views, there are different difficulties that limit their teaching work linked to ESD (Table 5).

Table 5. Difficulties to include the ESD in the teaching of the subjects.

\begin{tabular}{lll}
\hline \multicolumn{1}{c}{ Item } & Mean & Standard Deviation \\
\hline Insufficient duration of class time & 3.81 & 1.20 \\
\hline Excessive number of students per class & 3.51 & 1.32 \\
\hline Incorporating the ESD in my subjects implies financial support from the Administration. & 2.93 & 1.28 \\
\hline I don't have the necessary training to work on sustainability. & 2.84 & 1.15 \\
\hline The curricula of the subjects are overloaded so there is no space to cover the ESD. & 2.63 & 1.34 \\
\hline The contents of my subjects have no relation to SD. & 2.28 & 0.98 \\
\hline $\begin{array}{l}\text { The policies of the Administration do not enable teachers to be flexible to modify their } \\
\text { teaching to apply ESD. }\end{array}$ & 2.14 \\
\hline I have no interest in including ESD in my teaching work & 1.51 \\
\hline
\end{tabular}

In this dimension, it is evident that the main difficulties teachers find in incorporating ESD in their classrooms are the insufficient duration of class time (3.81) and the excessive number of students per class (3.51). These items have obtained significantly high standard deviations (1.20 and 1.32 respectively), which indicates the heterogeneity of the responses.

The item that has obtained the lowest score is 'I have no interest in including ESD in my teaching work' (1.51). This result is encouraging since it indicates that disinterest is not perceived as a difficulty. Additionally, not seen as a barrier is that the content of their subjects has no relation to sustainable development (2.28) not that the policies of the administration do not enable teachers to be flexible in their teaching (2.14).

5.1.5. Dimension 5. Proposals for Improvements with Regard to Including Sustainability in Teaching Practices

This question has been devised as an open-ended question to enable the respondents to specify what types of activities they consider most appropriate to apply in order to develop sustainable competencies in their students. Many of the answers have revolved around activities, and most are linked to environmental content, exclusively, such as: planting trees, creating a school garden, collecting waste in natural environments, energy saving strategies, and calculation of carbon footprints. One of the proposals presents a more global activity: design a city with a sustainable economy, resource management, population, and renewable energies. Two responses are related to the resolution of conflicts through mediation.

Fourteen of the responses related to activities refer to EE (environmental education) activities, while only three refer to other ESD aspects. These results reveal how teachers directly identify ESD with EE, obviating that ESD is much broader and includes a great variety of activities that interrelate an infinity of contents, values, and competencies.

Regarding methodologies, there have only been three responses: naming cooperative methodologies, learning-service, and innovative methodologies. In addition, in reference to these competencies, four participants have suggested a social and civic competence while one included religious competence (Christian and human awareness).

It should be noted that the majority of respondents $(82 \%)$ have mentioned that they require some type of training in this aspect. The connection between the fact that some of the participants say they need training in cooperative methodologies and that they propose these as a resource to work on ESD should also be noted. Regarding the proposed activities, it is worth noting that these are directed more toward specific activities than to work ESD in a cross-curricular manner through methodologies, competencies, or work on values. 
5.1.6. Correlation between Competencies and Values Related to ESD, Which Are to be Promoted in the Class

In light of the results obtained in the questionnaire, a correlational analysis has been carried out to see what type of correspondence exists between the block of competencies and the block of values (Table 6).

Table 6. Correlation competencies - values.

\begin{tabular}{lcc}
\hline & & AVERAGE VALUES \\
\hline \multirow{2}{*}{ AVERAGE COMPETENCIES } & Pearson Correlation & $0.476^{* *}$ \\
\cline { 2 - 3 } & Sig. (bilateral) & 0.001 \\
\cline { 2 - 3 } & $\mathrm{N}$ & 43 \\
\hline
\end{tabular}

** significant correlation at the 0.01 level ( 2 tails).

Based on the analysis carried out, it is evident that there is a positive correlation between the competency block and the values block, which is why it is interesting to specify which values correlate with each competence since it will allow us to disseminate a trend of teaching practice linked to EDS among the teachers who are the object of our study.

Next, we show each one of the competences analyzed and the values associated to each one of them, according to their level of correlation (Table 7).

Table 7. Competences for sustainability and associated values.

\begin{tabular}{|c|c|c|c|}
\hline \multirow{2}{*}{ COMPETENCES } & \multirow{2}{*}{ CORRELATED VALUES } & \multicolumn{2}{|c|}{ CORRELATION } \\
\hline & & Pearson Correlation & Sig. \\
\hline \multirow{8}{*}{ REGULATION } & Respect for the environment & $0.531 * *$ & 0.000 \\
\hline & Coexistence norms & $0.703^{* *}$ & 0.000 \\
\hline & Conflict resolution & $0.619^{* *}$ & 0.000 \\
\hline & Human rights & 0.756 ** & 0.000 \\
\hline & Gender equality & $0.586^{* *}$ & 0.000 \\
\hline & Non-discrimination & $0.439 * *$ & 0.003 \\
\hline & Healthy habits & $0.581 * *$ & 0.000 \\
\hline & Peace & $0.619 * *$ & 0.000 \\
\hline \multirow{8}{*}{ ANTICIPATION } & Respect for the environment & $0.457^{* *}$ & 0.002 \\
\hline & Coexistence norms & $0.358 *$ & 0.018 \\
\hline & Conflict resolution & $0.491 * *$ & 0.001 \\
\hline & Human rights & $0.444^{* *}$ & 0.003 \\
\hline & Gender equality & $0.325 *$ & 0.034 \\
\hline & Non-discrimination & $0.325 *$ & 0.034 \\
\hline & Healthy habits & $0.436^{* *}$ & 0.004 \\
\hline & Peace & 0.334 * & 0.029 \\
\hline \multirow{5}{*}{$\begin{array}{l}\text { SYSTEMIC } \\
\text { THINKING }\end{array}$} & Respect for the environment & $0.369 *$ & 0.015 \\
\hline & Human rights & $0.449 * *$ & 0.003 \\
\hline & Gender equality & $0.396^{* *}$ & 0.009 \\
\hline & Non-discrimination & $0.396^{* *}$ & 0.009 \\
\hline & Healthy habits & $0.333 *$ & 0.029 \\
\hline \multirow{5}{*}{ STRATEGIC } & Respect for the environment & $0.402 * *$ & 0.008 \\
\hline & Human rights & $0.380 *$ & 0.012 \\
\hline & Gender equality & $0.430 * *$ & 0.004 \\
\hline & Non-discrimination & $0.430 * *$ & 0.004 \\
\hline & Healthy habits & 0.364 * & 0.016 \\
\hline \multirow{5}{*}{ CRITICAL THINKING } & Respect for the environment & $0.534^{* *}$ & 0.000 \\
\hline & Conflict resolution & $0.316^{*}$ & 0.039 \\
\hline & Gender equality & 0.337 * & 0.027 \\
\hline & Non-discrimination & $0.337 *$ & 0.027 \\
\hline & Healthy habits & $0.318^{*}$ & 0.038 \\
\hline COLLABORATION & Conflict resolution & 0.335 * & 0.028 \\
\hline SELF-AWARENESS & Non-discrimination & 0.358 * & 0.018 \\
\hline PROBLEM SOLVING & - & - & - \\
\hline
\end{tabular}


This table highlights the map of values that the surveyed teachers promote when working each competence. This roadmap shows, in turn, possible strengths and weaknesses that the teachers may experience when working with ESD in a transversal and integral way.

In this way and, according to the table, we observe how 'Regulation competence' has the most correlated values. According to the answers of the teachers, all the values referred to in the questionnaire are positively correlated with it, which reveal the transversality of this competence in the teaching professional practice.

The second competence with the most correlated values is Anticipation.' Again, all the values reappear even though some come with a more significant correlation (sig. 0.01) than others (sig.0.05).

Regarding, 'Systemic Thinking competence,' 'strategic competence,' and 'critical thinking', we see there are five values with significant correlation scores. The values that correlate with these competences and that are a constant in the three of them are: respect for the environment, human rights, gender equality, non-discrimination, and healthy habits. From this, we can infer that, parallel to the development of these competences, the teaching staff promotes certain environmental and social values. This may be not in an integral and transversal way since there are some values such as 'coexistence norms' or 'conflict resolution' that do not show a strong correlation.

Lastly, when it comes to the 'collaboration' and 'self-awareness' competencies, only 'conflict resolution' and 'non-discrimination' values are correlated, respectively. A special case is 'problem solving' where the results show a currently existing correlation to any of the analyzed values. The data, in general, show that the work of these competencies on the part of the surveyed teachers is diverse. There is no explicit correlation with the development of specific socio-environmental values.

\subsection{Results Derived from the Interviews with EGS Members}

For the analysis of the interviews undertaken with EGS members, an analysis of contents by dimensions has been carried out.

\subsubsection{Dimension 1. Beliefs and Attitudes about Education for Sustainable Development}

When undertaking an in-depth analysis of the interviews carried out with the EGS members, it can be noted that all of them agree that ESD should be encouraged not only within informal and non-formal education, but also with formal education.

They all also agree that all subjects should be addressed from an ESD perspective and point out that it should be done in a cross-curricular way. Several of them point out that the use of cooperative and innovative methodologies contributes to the implementation of ESD in all subjects. Likewise, the general view is that all subjects are susceptible to adapting to this approach, which, in some cases, suggests the use of certain methodologies, such as:

'Taking as basis the nexus of the skeleton of a project that will affect a great many subjects, work (through) learning-services within the improvement in their own town, in an environment that will always be closer to them. Instead of telling them about the melting of Antarctica, which may concern them, it would be more appropriate, for children in primary education in this case, to get closer to what happens on the level of those natural systems close to their own environments and speak about what they can do to improve this, to commit...'

(Subject 1).

Regarding the way in which ESD can be promoted from the field of guidance, and from the EGS in particular, they agree to highlight the importance of counselling and tutorial action by providing a variety of suggestions: advice to teachers on methodologies, concrete actions during the tutorial group sessions, introduction of ESD in the Tutorial Action Plan, advice to the school leadership team in the elaboration of the Educational Project, advice and participation in the technical teams of Educational 
Coordination and in the faculties, contribution in the elaboration of the Curricular Project of the Center, and in the programming of areas, coordination, and promotion of concrete actions, advice to families, and through education in values and work by competences, which highlight social and civic competence.

\subsubsection{Dimension 2. Shortcomings Linked to the Inclusion of Content Related to ESD}

Therefore, the great importance that all team members give to ESD is reflected. When asked about the values and attitudes that can be worked on from this approach, the vast majority agree that the following should be pointed out: solidarity, equality, respect, empathy, cooperation, and commitment. They add: awareness, communication, active listening, resolution of conflicts, dignity, avoidance of consumerism, motivation, and tolerance. The broad answers given to this question denote that there is a perception on the part of the counsellors that an infinity of values can be addressed through ESD.

Regarding the question of whether they think that, in the schools where they work, sustainability and the values promoted by the ESD are fostered. We find heterogeneity in the answers. 'Subject 1 ' believes that, currently, we work in an anecdotal and ad-hoc manner. 'Subject 6' states that a lot of work is being done and that the teaching staff is very aware. However, he points out that there has not been any actual implementation of those innovative methodologies that are in line with this approach. 'Subject 5' notes that work is being done, but not in the depth that it should be, and 'Subject 2 ' mentions that the problem is that it is the teachers that choose whether to work on certain values or not. Therefore, we can find teachers who delve into work on values, while there are others who do not address these issues. He adds that, in his point of view, work is generally being done in an occasional and decontextualized way.

The diversity of responses may be due to the subjectivity that this question implies, and also to the fact that the counsellors work at different centers, so they witness different realities. However, a common response is detected. It is addressed only in an ad-hoc and anecdotal manner.

\subsubsection{Dimension 3. Teaching Competences in Sustainability Matters}

As to whether they consider that teachers have the necessary training and skills to work from the ESD approach, the general view is that they are not sufficiently trained. The majority point out that the training depends on the teachers' own will, so they find teachers with high motivation who spend time and effort in their training, and teachers who, once they are working, do not undertake further training. They point out that the training is available in reference to the Center for Teachers Education and to specific resources that they look for on their own, but note that ultimately further training depends on the teachers' will.

'Subject 1' makes an interesting contribution, which suggests that sometimes previous training is not as important as starting to work and training, according to the needs that arise.

'I believe that we have to work on competencies as we get involved in the issue, because we often wait until we have received the perfect training, until the perfect moment, until everything is perfect, and experience has told me that we build as we learn, and as I take a step, although I may be not sure where the next step will lead me, where it can go, but while I'm taking the step and I'm raising my foot, I'm already looking, getting training, but I've already begun to take steps, I've already begun to move. Because otherwise, the perfect moment never exists and will never arrive.'

(Subject 1).

When we asked what guidance activities they carry out to work on the values and competences, they indicate the suitability of the implementation of methodologies that promote ESD. They indicate that their contribution is through methodological advice, using service-learning as an example. Other team members explain that their guidance actions related to ESD are channeled through tutorials, programs, and projects related to conflict mediation and resolution, emotional education, 
and social competence. 'Subject 5 ' adds the advice in the curricular project and the elaboration of school documents.

\subsubsection{Dimension 4. Difficulties of Including ESD within the Teaching of a Subject}

When talking about the difficulties that teachers encounter to include ESD in schools, four of the counsellors point to the overriding curricular burden felt by teachers as the main reason. They argue that the regulations dictate a very broad curriculum that hardly allows the introduction of other topics. However, some detect that this may be due to the teachers' identification of the curriculum with the textbook:

'If we understand the book as a syllabus then it is true, they do not have time to address anything. But the truth is that the book is not the syllabus, the book is an aid that can be used, to a greater or lesser extent, to deliver the syllabus. And the syllabus is the list of objectives and content given by the Administration, which is sufficiently general so that this content can be included, and achieve the objectives stipulated by the Administration'.

(Subject 5).

Lack of training and knowledge, support, and time add to these difficulties. Furthermore, the excess of bureaucratic tasks and the decreasing motivation and implication levels are seen over time.

Regarding the difficulties faced by counsellors when working with teachers on this issue, there is a unanimous response: a lack of time. Many of them compare the time that can be dedicated to each center when you belong to an EGS and need to attend several centers each week, with the time you have when working in the guidance department of a high school.

They also agree that, with the development of prescriptive tasks such as psycho-pedagogical evaluations, the updating of reports, advice to families or schooling reports, there is barely any time left for other interventions. Some of them add that it is necessary that the center itself includes it in the design of its educational project.

On the question of what the predisposition of schools and EGSs to foster this approach is, the answers show that the team perceives that there is more predisposition on their part than on the centers' part. They expand on this response by pointing out that the centers are very different from each other, and, while some are up for the task of innovating, others are not so eager, or are predisposed to work on it, but only in an ad-hoc way.

When talking about the predisposition of the EGS, they emphasize the tendency to innovation that exists in the team, and the desire to go beyond mere evaluations:

'In this orientation team, I believe that one of the most positive things we have is that we are always open to working on everything, and above all, that we understand the orientation as something beyond the evaluation itself, and see it as a methodological change, as how to try to change the relationship with the environment'.

(Subject 1).

When talking about counsellors' strengths to work on this approach with teachers, we find a variety of answers, which provide many ideas that are complementary, about their strengths. These include having more time than teachers, the systematic ability to understand that learning involves transforming the environment, having training on how to integrate this approach into the curriculum, in a cross-curricular manner, the vision held by teachers on counsellors, as an external agent, which results in them being taken into account more, the zonal perspective that provides the possibility of disseminating successful educational projects, and their own awareness about attention to diversity and ecological, economic, and social sustainability.

When the question arises on what are the needs of both teachers and EGS in terms of advice, guidance, and training in this field, there is a word that appears in all the answers: training, for both 
teachers and counsellors. Some of them specify that it would be useful to have training in cooperative methodologies such as learning-services and in new technologies. Another of the most frequent answers is the request for the provision of material resources, such as specific programs, and they add to this: assessment tools and instruments, that the ESD becomes part of the curriculum and is evaluated, and exchange of good practices with other centers.

\subsubsection{Dimension 5. Improvement Proposals for Including Sustainability in Teaching Practice}

When talking about specific guidance actions to improve or include ESD in schools, four of the team members suggest counselling on cooperative methodologies, proposing learning-service, cooperative learning, and project-based learning. Two of them emphasized the strength of having a zonal perspective by considering making the most of it and make proposals that arise from here, which act in a systemic way. Two people also proposed to promote work on values. These proposals are complemented with: help to review schedules, collaborate in the design of tasks that organize learning, and provide advice on specific activities, materials, and programs.

Lastly, in relation to the question of what improvements must be made at the educational center and on a classroom level, both at the levels of management and teaching practice, we find great diversity in the responses. However, there is a common response: to encourage cooperative methodologies (project-based learning, cooperative learning, and individualized learning based on meaningful learning by discovery). To which they add: review the schedules and methodologies, including content that is really relevant, foster exchanges of ideas within the centers themselves, sharing the successful experiences that take place in the classrooms, reduce the student ratio, boost shared leadership, and carry out sustainable practices within the classroom (reduction of consumption, separation of waste, evaluation of energy expenditure, etc.).

To end, and in order to make quantitatively visible the results obtained with these interviews, a count of the words that are most repeated across the five dimensions has been carried out using the $\mathrm{N}$-Vivo 10 program, obtaining the frequency of the 50 most used words (Table 8 ) and a word cluster (Figure 3) to see the terms more visually. To do this, the transcripts of the interviews were previously coded by categorizing the answers, according to the analysis dimensions.

Table 8. Frequency of terms extracted from the interview transcription.

\begin{tabular}{|c|c|c|c|c|c|}
\hline Term & Freq. & Term & Freq. & Term & Freq. \\
\hline schools & 60 & curriculum & 19 & awareness-raising & 10 \\
\hline topics & 43 & team & 19 & difficult & 10 \\
\hline work & 41 & peace & 17 & now & 9 \\
\hline projects & 35 & faculty & 17 & coordination & 9 \\
\hline values & 34 & learning & 15 & development & 9 \\
\hline training & 32 & tutorial & 15 & important & 9 \\
\hline doing & 32 & counseling & 14 & objectives & 9 \\
\hline time & 30 & contents & 14 & counselor & 9 \\
\hline education & 29 & day & 14 & planet & 9 \\
\hline example & 29 & children & 14 & primary education & 9 \\
\hline environment & 28 & power & 14 & problem & 9 \\
\hline being & 23 & respect & 13 & recycling & 9 \\
\hline programs & 22 & social & 13 & resources & 9 \\
\hline equality & 22 & activities & 11 & high school & 9 \\
\hline us & 21 & guidance & 11 & classroom & 8 \\
\hline form & 20 & being able & 11 & manager & 8 \\
\hline methodology & 20 & competences & 10 & & \\
\hline
\end{tabular}




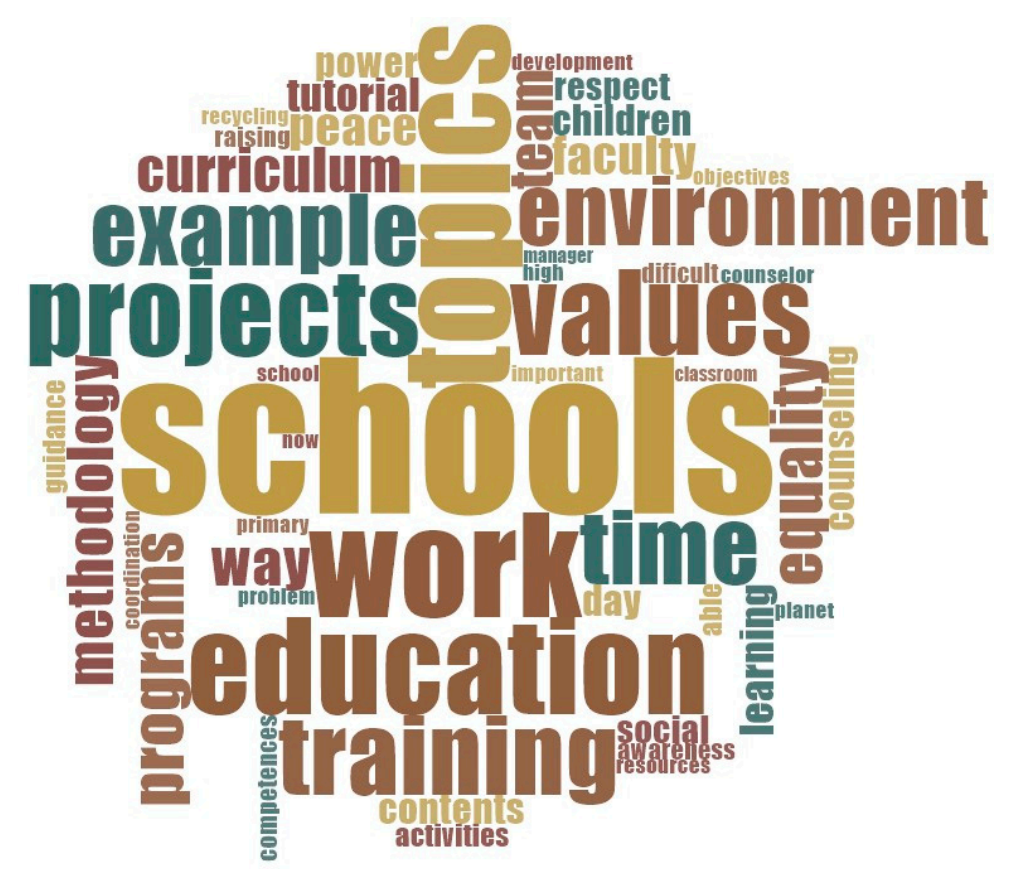

Figure 3. Word cloud extracted from interview transcription. Source: own elaboration.

We can confirm through these new analyses that the counselors' attention revolves around the projects that are carried out in schools. They pay special attention to the values fostered in educational programs, among which we can find peace, equality, and respect for the environment, generating in the students' attitudes of commitment toward recycling and the management of resources. Likewise, they believe that working on these types of competencies in educational centers can be, a priori, complicated. However, the transmission and learning of curricular content can be achieved through appropriate coordination as well as by working with innovative methodologies and including the adequate training of teachers in the process. All this helps us to achieve the inclusion of education for sustainable development in a satisfactory way in the primary and secondary school curricula and, with it, the development of competencies related to sustainability.

\section{Discussion}

The case study presented has sought to verify the relevance and suitability of counselling as one of the ways to promote ESD and, thereby, endorse the development of key skills linked to sustainability.

Once the data obtained from each of the instruments used have been presented, it is important to carry out a process of discussion of the results that shows the state of the EGS in the development of key competencies that are linked to the ESD as well as the shortcomings and the proposals that are outlined for improvement.

Regarding the first specific research objective, which refers to an analysis of the beliefs and attitudes about ESD, it can be observed that, on the part of the EGS members, there is a more positive attitude towards ESD because the answer was unanimous: 'ESD is very important. It must be promoted from the formal education arena and is susceptible to fit within all curriculum subjects'. On the other hand, the response of teachers has been more diverse. Although they show a positive attitude towards the general idea that students should learn about sustainability, when the questions specifically focus on whether it should be promoted from within a formal education setting, the answer is very heterogeneous, which reveals that there is a part of teachers who think that it should only be promoted from non-formal and informal educational spheres. It has also become clear that not all teachers think that all subjects fit with the teaching of ESD.

This more positive attitude on the part of the counsellors may be due to the fact that the counselling has a more holistic vision by taking into consideration the importance of addressing 
cross-curricular issues and advocates the implementation of innovative methodologies that allow the actual implementation of cross-curricular approach.

Among the functions of educational guidance is to help teachers improve their daily practice in the classroom by introducing methodologies that include more effective, integrative, and educational practices $[38,40]$. Guidance professionals can encourage innovation and improvement by assisting teachers in their processes of methodological change, which helps improve the overall development of students.

With regard to the second specific objective of analyzing the inclusion of content and values linked to sustainability, the teachers surveyed show a heterogeneous tendency regarding framing said content in the ESD. This tendency is due, in part, to their unfamiliarity with the ESD concept. This statement is inferred from the responses given to questions where they had to show content, activities, values, and specific skills to work on ESD since these responses reflect the identification of ESD almost exclusively within purely environmental topics. Similarly, a general difficulty when working ESD in a cross-curricular manner can be seen. As several authors point out, there are difficulties when working ESD in this cross-curricular way due to a lack of training, materials and resources, time, coordination among teachers, recognition and support. Due to school secrecy, the stagnant culture of the school and the isolated work of teachers $[33,34]$.

In respect to Objective 3, addressed from the identification of those professional competencies linked to education for sustainability, the teachers state that they work on all the values promoted by ESD. The EGS members, even if their opinions are varied, all agree that, in their opinion, the work on values carried out by the teaching staff is ad-hoc and anecdotal. The fact that teachers coincide in affirming that all values are worked on in depth, coincides with the fact that work on values has long been promoted both socially and legislatively.

It seems to be a fact that teachers have assumed that they do carry out work on values because it is very present in the discourse on education. However, some authors point out that, due to the rigidity in the proposal of the curricular design, which tries to assign a section on values across all the blocks of content, the outcome is that they are worked on only on specific occasions, striving to 'fill gaps' or meet administrative requirements, rather than being worked on as a true reflective process about values [35,41].

Regarding their contribution as counsellors for work by competencies, several of them agree that one of the best ways is to provide counselling on methodologies that allow and encourage the promotion of these competencies.

Teachers have agreed in stating that they work on quite a lot of competencies related to ESD. According to them, the competence they work on the most are related to education in values, and they work a little less on more complex competencies than would be more directly related to ESD. This is directly related to the fact that the values and competencies analyzed are not specific to ESD, but have been included in educational legislation for a long time now. On the other hand, ESD has not been widely promoted, so teachers are not very familiar with the concept.

For Objective 4, which aims to outline the difficulties encountered by teachers to include ESD in Formal Education, we find important differences between the opinion of teachers and that of the EGS members. The counsellors coincide in pointing out that the greatest difficulty that teachers have to include ESD is the excessive curricular burden, while teachers have given very heterogeneous answers to the questionnaire, which shows that a large part of them do not perceive the curricular burden to be a difficulty.

This data is odd because the rigidity of the curriculum is usually a common complaint on the part of teachers, but, when it is presented as a possible difficulty to include ESD, many do not perceive it as such. On the other hand, they have indicated (although with a high heterogeneity in the answers) the excessive number of students per class and the lack of time as greater difficulties. A relationship can be found between that lack of time and the excessive curricular content since it seems to be the same concept presented in a different way. In addition, it is not surprising that they mention the excessive 
number of students because the ratio of students in Spain is a common public complaint made by the education sector.

It is noteworthy that the counsellors think that teachers identify curriculum exclusively with the textbook, which suggests that they are not flexible enough to adapt this curriculum. However, when asked about their own difficulties in including ESD, they point out a lack of time and an excess of prescriptive tasks as the main reasons. This fact is widely perceived as an obstacle, arguing that there are many important tasks, frequently urgent, that often block the ability to be more flexible.

Many of the tasks set by the regulations are not usually solved and priority is given to other tasks that are more urgent but less effective. For this reason, we advocate counselling as an essential function, defining its ability to generate improvement processes that ensure desirable educational levels preferred for all students. With the analysis of the answers given by the teaching staff and the counsellors, it becomes clear that there is an overload of tasks that prevent the development of a quality education. To solve this situation, legislative measures and support from the administration are needed, but a change in the teachers and counsellors' own perception is required, so that they strive to be innovative and try to change the trends, which are currently so corseted by taking into consideration a change in their own practice [2,41].

Lastly, in relation to Objective 5, which was nothing other than to identify proposals to improve the development of professional competencies in education for sustainability, EGS members agree that both they and teachers need, in order to improve their practice in this regard, specific training. Several of them mention training in methodologies related to ESD. They also point out the endowment of material resources and specific programs.

We should remember that $82 \%$ of teachers had indicated that they needed training. Some have agreed with the members of the EGS in pointing out the need for training in methodologies. Those who have specified what training content they require have pointed out specific EE content, which makes it clear that they have a reductionist idea about ESD since none has mentioned any other type of content [21,22].

In relation to this, the improvement proposals put forward by the teachers show yet again that they relate ESD to EE exclusively, since $82 \%$ have proposed specific activities within the EE framework. The problem is not that they make this type of proposal because these are interesting activities, but that they propose very specific activities that are so exclusive to EE that they detract from the potential of ESD, which can provide a much richer variety of activities, diversity of contents, values, and competencies at the same time.

In contrast, EGS members have proposed advice with special emphasis on cooperative methodologies that encourage ESD. These responses show a greater understanding of ESD since it is understood as a broader and more complex paradigm $[10,11,56]$.

Lastly, in our case study, a correlational map of competencies for sustainability and values is evident, which shows how this faculty works with ESD in their classroom. In this sense, this finding can be the starting point for the characterization of the professional practice of teachers and counselors by taking into account the values they transmit from working competence for sustainability. On the other hand, it also expresses the weaknesses and strengths in EDS that the professors of our case study show in this field of work. I have been shown that transverse and integral work required to incorporate sustainability into the classroom is still a pending task for teachers. Although, there are sustainability competencies that this faculty works in a transversal way through the values that it transmits (e.g., 'Regulation competence' or 'Anticipation'), the absence of the correlation of these values with some competencies denotes that some of them are worked in a linear and punctual way (e.g., 'Collaboration' or 'Problem solving').

\section{Conclusions}

This research work has tried to shed some light into the relation, the benefits, and impact that educational guidance can have for the development of professional competencies in the area of 
Education for the Sustainability, given that research linked to this professional practice barely exist. The data obtained reveal the perception and needs that are identified by teachers and the guidance team with regard to this topic as well as the courses of action that the educational guidance provides to promote ESD and proposals for improvement to transform the current state of reality.

Thanks to this research, it has been ratified that, as in other contexts, it has been possible to verify that counselling on participatory methodologies, the work on values, the cross-curricular nature of the content, the work on competencies, and the curricular sustainability are the most effective ways from which the guidance team can promote the implementation of ESD in educational centers. Likewise, it has become clear that more training on ESD is necessary for both the teaching staff and the guidance team.

It is clear that the holistic capacity, zonal perspective, and extensive educational training that EGS members have is a strength that must be taken advantage of as much as possible to carry out educational counselling processes that include ESD.

Given this situation, the study reveals some possible work proposals already derived in the theoretical framework, which can aim to cover the identified shortcomings and improve the current reality in this area. Some of these proposals are:

- Expand the vision of SD (Sustainable Development), which is commonly identified with recycling, waste treatment, cleaning, and pollution in generic terms.

- Encourage reflexive processes on the interconnection of all the elements to face 'environmental long-sightedness,' which consists of giving greater importance to what is closer than to what is at a distance.

- $\quad$ Demand legislative changes because one of the limits found by schools is a highly-bureaucratized administration system that is not capable of managing complex, multidimensional, and interdisciplinary projects such as those proposed by the ESD.

- Encourage the involvement of the school management team as well as greater administrative involvement to promote this type of project since this is vital for its effectiveness.

The positive influence that the process itself has had should be highlighted as an achievement of the research. This research has favored that those professionals who have participated in the study gain greater knowledge about competencies required to incorporate ESD into their professional practice and an opportunity to reflect on it.

On the other hand, another finding has been to determine the correlation that can exist between the socio-environmental values that are worked in the classroom and the competencies for sustainability in order to generate an interrelated action framework. This entails a road map from which generating new research that helps outline how the transmission of values influences the development of competences related to sustainability, and that shows the strengths, weaknesses, and difficulties that teachers and counselors exhibit when incorporating ESD in a complex, transversal, and integral way. It can be considered a roadmap that may serve as a starting point for viable and coordinated improvement strategies.

With respect to the case study that we present in this report, in order to obtain richer and more reliable data, and to understand this phenomenon in depth, broader samples of both counsellors and teachers are required, as well as finer qualitative analyses and more participatory and collegial research designs among counsellors, teachers, and researchers that also favor the transfer of knowledge and results outside the educational center.

However, through the data obtained and the conclusions drawn, sufficient arguments are offered for a thorough review, reconstruction, and improvement of policies, practices, and training in the field of ESD from educational guidance. This work opens a line of research that would be very interesting to continue: ESD through the perspective of Educational Guidance.

Regarding future work, an interesting line of research to follow comes from the analysis of 'ESD through the perspective of Educational Guidance' and the expansion of the results and messages 
coming from this particular Spanish case study to the broader regional and global community working to promote ESD. There is, therefore, an opportunity to channel professional practice toward the previously mentioned counselling by trying to move away from the vision of counsellors as 'fire-extinguishers' and moving toward a professional figure that provides support and advice, capable of motivating and guiding the entire educational center to inject the ESD paradigm into the management of the center.

It has been proven that, through the theoretical review and the analysis of the opinion of teachers and counsellors, the implementation of innovative and cooperative methodologies is perceived as one of the most effective ways to promote ESD, since they make possible cross-curricular approaches and allow improvements to education in all its aspects and dimensions.

ESD is an essential tool to create more sustainable societies, so we must stand behind it and promote it from educational guidance outward. Educating students in sustainability is not betting on a better future, but betting on a better present, because children are environmentally-competent citizens capable of generating changes in their environment.

Author Contributions: Conceptualization, F.P.-V., A.L.-A., and N.M.-C. Methodology, F.P.-V., A.L.-A., and N.M.-C. Software, A.L.-A. and N.M.-C. Validation, F.P.-V. and A.L.-A. Formal analysis, F.P.-V., A.L.-A., and N.M.-C. Research, F.P.-V. and N.M.-C. Resources, N.M.-C. Data curation, N.M.-C. Writing-original draft preparation, F.P.-V. and N.M.-C. Writing-review and editing, F.P.-V., A.L.-A., and N.M.-C. Visualization, F.P.-V., A.L.-A., and N.M.-C. Supervision, F.P.-V. Project administration, F.P.-V.

Funding: This research received no external funding.

Conflicts of Interest: The authors declare no conflict of interest.

\section{References}

1. Delors, J. La Educación Encierra un Tesoro; Santillana/Unesco: Madrid, Spain, 1997.

2. Wiek, A.; Bernstein, M.; Foley, R.; Cohen, M.; Forrest, N.; Kuzdas, C.; Withycombe, L. Operationalising competences in higher education for sustainable development. Handbook of Higher Education for Sustainable Development; Routledge: Abingdon, UK, 2015; pp. 241-260.

3. Wiek, A.; Withycombe, L.; Redman, C.L. Key competences in sustainability: A reference framework for academic program development. Sustain. Sci. 2011, 6, 203-218. [CrossRef]

4. Leal, W.; Manolas, E.; Pace, P. The future we want: Key issues on sustainable development in higher education after Rio and the UN decade of education for sustainable development. Int. J. Sustain. High. Educ. 2015, 16, 112-129. [CrossRef]

5. Cebrián, G.; Junyent, M. Competencias profesionales en Educación para la Sostenibilidad: Un estudio exploratorio de la visión de futuros maestros. Enseñ. Cienc. 2014, 32, 29-49. [CrossRef]

6. CEE. Recommendation of the European Parliament and of the Council, of 18 December 2006, on Key Competences for Lifelong Learning. 2006. [Official Journal L 394/11 of 30.12.2006]. Available online: http:// europa.eu/legislation_summaries/education_training_youth/lifelong_learning/c11090_en.htm (accessed on 20 December 2018).

7. OCDE. The Definition and Selection of Key Competences (DeSeCo). 2002. Available online: http://www. oecd.org/education/skills-beyond-school/definitionandselectionofcompetencesdeseco.htm (accessed on 20 December 2018).

8. Caniglia, G.; John, B.; Kohler, M.; Bellina, L.; Wiek, A.; Rojas, C.; Lang, D. An experience-based learning framework: Activities for the initial development of sustainability competences. Int. J. Sustain. High. Educ. 2016, 17, 827-852. [CrossRef]

9. Ofei-Manu, P.; Didham, R.J. Identifying the factors for sustainability learning performance. J. Clean. Prod. 2018, 198, 1173-1184. [CrossRef]

10. Ofei-Manu, P.; Didham, R.J. Quality Education for Sustainable Development: A Priority in Achieving Sustainability and Well-being for All. In IGES Policy Brief; IGES: Hayama, Japan, 2014.

11. Iyer-Raniga, U.; Myla-Andamon, M. Transformative learning: Innovating sustainability education in built environment. Int. J. Sustain. High. Educ. 2016, 17, 105-122. [CrossRef] 
12. Li, C.J.; Monroe, M.C.; Ritchie, T. Integrating social science research to advance sustainability education. In Handbook of Sustainability and Social Science Research; World Sustainability Series; Leal Filho, W., Marans, R., Callewaert, J., Eds.; Springer: Cham, Switzerland, 2018.

13. Sterling, S. Transformative learning and sustainability: Sketching the conceptual ground. Learn. Teach. High. Educ. 2011, 5, 17-33.

14. Sterling, S. An analysis of the development of sustainability education internationally: Evolution, interpretation and transformative potential. In The Sustainability Curriculum: The Challenge for Higher Education; Blewitt, J., Cullingford, C., Eds.; Earthscan Publications: London, UK, 2004; pp. 43-62.

15. UNESCO. Educación para el Desarrollo Sostenible. Libro de Consulta. 2012. Available online: https: / / unesdoc.unesco.org/ark:/48223/pf0000216756 (accessed on 20 December 2018).

16. UNESCO. Educación para los Objetivos de Desarrollo Sostenible. Objetivos de Aprendizaje. 2017. Available online: https:/ /www.researchgate.net/publication/325570670_Educacion_para_los_Objetivos_ de_Desarrollo_Sostenible_Objetivos_de_aprendizaje (accessed on 20 December 2018).

17. Gutiérrez-Pérez, J.; Poza-Vilches, M.F. Environmental citizenship training skills: Sustainable management municipalities with action research \& local agenda 21. Int. J. Interdiscip. Soc. Sci. 2012, 6, 151-168.

18. López-Alcarria, A.; Gutiérrez-Pérez, J.; Perales-Palacios, F.J.; Burgos-Peredo, O. Greening the curricula: A comparison between Primary and Secondary Eco-school Projects. Int. J. Sustain. Educ. 2013, 9, 1-18. [CrossRef]

19. Mckeown, R. Manual de Educación para el Desarrollo Sostenible; Centro de Energía, Medio Ambiente y Recursos, Universidad de Tennessee: Knoxville, TN, USA, 2002.

20. Didham, R.J.; Ofei-Manu, P. Advancing Education for as a Goal for Sustainable Development. In IGES Issue Briefs on SDGs Series; IGES: Hayama, Japan, 2013; Available online: https: / / www.files.ethz.ch/isn/170642/ IGES_-_SDG_Issue_Brief_2_-_Education.pdf (accessed on 20 December 2018).

21. Bürgener, L.; Barth, M. Sustainability competences in teacher education: Making teacher education count in everyday school practice. J. Clean. Prod. 2017, 174, 821-826. [CrossRef]

22. Murga-Menoyo, M.A.; Novo, M. Sostenibilidad, desarrollo «glocal» y ciudadanía planetaria. Referentes de una Pedagogía para el desarrollo sostenible. Teoría Educ. Rev. Interuniv. 2017, 29, 55-78. [CrossRef]

23. Sinakou, E.; Boeve-de, J.; Maarten, P. Academics in the field of Education for Sustainable Development: Their conceptions of sustainable development. J. Clean. Prod. 2018, 184, 321-332. [CrossRef]

24. Berglund, T.; Gericke, N. Separated and integrated perspectives on environmental, economic, and social dimensions e an investigation of student views on sustainable development. Environ. Educ. Res. 2016. [CrossRef]

25. Gustafsson, P.; Engström, S.; Svenson, A. Teachers' view of sustainable development in Swedish upper secondary school. Procedia Soc. Behav. Sci. 2015, 167, 7-14. [CrossRef]

26. Birdsall, S. Measuring student teachers' understandings and self-awareness of sustainability. Environ. Educ. Res. 2014, 20, 814-835. [CrossRef]

27. Borg, C.; Gericke, N.; Höglund, H.O.; Bergman, E. Subject- and experiencebound differences in teachers' conceptual understanding of sustainable development. Environ. Educ. Res. 2014, 20, 526-551. [CrossRef]

28. Kilinc, A.; Aydin, A. Turkish student science teachers' conceptions of sustainable development: A phenomenography. Int. J. Sci. Educ. 2013, 35, 1-22. [CrossRef]

29. Ärlemalm-Hagser, E.; Sandberg, A. Sustainable development in early childhood education: In-service students' comprehension of the concept. Environ. Educ. Res. 2011, 17, 187-200. [CrossRef]

30. Summers, M.; Childs, A. Student science teachers' conceptions of sustainable development: An empirical study of three postgraduate training cohorts. Res. Sci. Technol. Educ. 2007, 25, 307-327. [CrossRef]

31. Spiropoulou, D.; Antonakaki, T.; Kontaxaki, S.; Bouras, S. Primary teachers 'literacy and attitudes on education for sustainable development. Res. Sci. Technol. Educ. 2007, 16, 443-450. [CrossRef]

32. Melendro, M.; Murga, M.Á.; Novo, M.; Bautista-Cerro, M.J. Estrategias formativas innovadoras en educación ambiental y para el desarrollo sostenible. RIED. Rev. Iberoam. Educ. Distancia 2008, 11, 15-39. [CrossRef]

33. Murga-Menoyo, M.A. Competencias para el desarrollo sostenible: Las capacidades, actitudes y valores meta de la educación en el marco de la Agenda global post-2015. Foro de Educ. 2015, 13, 55-83. [CrossRef]

34. Aramburuzabala, P.; Cerrillo, R.; Tello, I. Aprendizaje-servicio: Una propuesta metodológica para la introducción de la sostenibilidad curricular en la Universidad. Rev. Profr. 2015, 19, 78-95. 
35. Evans, N.; Stevenson, R.; Lasen, M.; Ferreira, J.A.; Davis, J. Approaches to embedding sustainability in teacher education:A synthesis of the literature. Teach. Teach. Educ. 2017, 63, 405-417. [CrossRef]

36. Chinedu, C.C.; Wan-Mohamed, W.A. Essential Elements of Sustainability for Technical and Vocational Teacher Education: Perspectives from Sustainability Expert. In Proceedings of the 7th World Engineering Education Forum (WEEF), Kuala Lumpur, Malaysia, 13-16 November 2017; pp. 617-623.

37. UNESCO. Unesco Education Strategy 2014-2021; UNESCO: Paris, France, 2014.

38. Ramos, T.B.; Caeiro, S.; van Hoof, B.; Lozano, R.; Huisingh, D.; Ceulemans, K. Experiences from the implementation of sustainable development in higher education institutions: Environmental Management for Sustainable Universities. J. Clean. Prod. 2017, 106, 3-10. [CrossRef]

39. Leal, W.; Raath, S.; Lazzarini, B.; Vargas, V.R.; de Souza, L.; Anholon, R.; Quelhas, O.L.G.; Haddad, R.; Klavins, M.; Orlovic, V.L. The role of transformation in learning and education for sustainability. J. Clean. Prod. 2018, 199, 286-295. [CrossRef]

40. Howlett, C.; Ferreira, J.; Blomfield, J. Teaching sustainable development in higher education. Int. J. Sustain. High. Educ. 2016, 173, 305-321. [CrossRef]

41. Barrero, B.; Domingo, J.; Fernández, J. La función de asesoría para la mejora de la enseñanza y el aprendizaje en la práctica profesional de un orientador de zona. Un estudio de caso. Educ. Siglo XXI 2014, 32, 151-172.

42. Fernández, L.F. Hacer Posible lo Contrario. Enseñar y Aprender de Otra Manera; Delegación Territorial de Educación, Cultura y Deporte de Granada, Junta de Andalucía: Granada, Spain, 2015. Available online: https: / / equipotecnicoorientaciongranada.files.wordpress.com/2014/11/hacerposiblelocontrario.pdf (accessed on 20 December 2018).

43. Chinedu, C.C.; Wan-Mohamed, W.A.; Ogbonnia, A. A systematic review on education for sustainable development: Enhancing TVE teacher training programme. J. Tech. Educ. Train. 2018, 10, 109-125.

44. Ramos, J.; Cuadrado, I.; Fernández, I. Valoración del funcionamiento de los Equipos de Orientación Educativa y Psicopedagógica. Rev. Iberoam. Educ. 2007, 43, 1-14.

45. Wisdom, J.; Creswell, J.W. Mixed Methods: Integrating Quantitative and Qualitative Data Collection and Analysis While Studying Patient-Centered Medical Home Models; Agency for Healthcare Research and Quality Publication: Rochville, Germany, 2013.

46. Mertens, D.M. Transformative Mixed Methods: Addressing Inequities. Am. Behav. Sci. 2012, 56, 1-12. [CrossRef]

47. Mertens, D.M. Transformative Research and Evaluation; Guilford: New York, NY, USA, 2009.

48. Shields, P.; Rangarajan, N. A Playbook for Research Methods: Integrating Conceptual Frameworks and Project Management; New Forums Press: Stillwater, DC, USA, 2013.

49. Bisquerra, R. Metodología de la investigación educativa; La Muralla: Madrid, Italy, 2009.

50. Kilgour, P.; Reynaud, D.; Northcote, M.T.; Shields, M. Role-playing as a tool to facilitate learning, self-reflection and social awareness in teacher education. Int. J. Innov. Interdiscip. Res. 2015, 2, 8-20.

51. Gün, B. Quality self-reflection through reflection training. ELT J. 2010, 65, 126-135. [CrossRef]

52. Putney, L.G.; Broughton, S. Developing teacher efficacy through reflection: A Vygotskian perspective. Crit. Issues Teach. Educ. 2010, 17, 4-17.

53. Hancock, D.R.; Algozzine, B. Doing Case Study Research: A Practical Guide for Beginning Researchers; Teachers College Press: New York, NY, USA, 2016.

54. Yin, R.K. Case Study Research and Applications: Design and Methods; Sage Publications: Thousand Oaks, CA, USA, 2017.

55. Yin, R.K. Applications of Case Study Research; Sage Publications: Thousand Oaks, CA, USA, 2011.

56. Baxter, P.; Jack, S. Qualitative Case Study Methodology: Study Design and Implementation for Novice Researchers. Qual. Rep. 2008, 13, 544-559.

57. Guba, E.G.; Lincoln, Y.S. Effective Evaluation: Improving the Usefulness of Evaluation Results through Responsive and Naturalistic Approaches; Jossey-Bass: San Francisco, CA, US, 1991.

58. Bustos, R.; Campos, S.; Majadas, J. Educación para la Sostenibilidad: Investigación Sobre el Impacto de las Metodologías Participativas; Fundación Entretantos: Valladolid, Spain, 2016.

59. Hussein, A. The use of triangulation in social sciences research: Can qualitative and quantitative methods be combined? J. Comp. Soc. Work 2015, 4, 1-12. 
60. Yilmaz, K. Comparison of quantitative and qualitative research traditions: Epistemological, theoretical, and methodological differences. Eur. J. Educ. 2013, 48, 311-325. [CrossRef]

61. Bekhet, A.K.; Zauszniewski, J.A. Methodological triangulation: An approach to understanding data. Nurse Res. 2012, 1-11. [CrossRef] 